\title{
JAUNESNIOJO MOKYKLINIO AMŽIAUS VAIKŲ FIZINIO PAJĖGUMO ANALIZE் LIETUVOJE: 2016 METŲ STUDIJA
}

\author{
Irina Klizienė ${ }^{1}$, Gintautas Cibulskas ${ }^{1}$, Audronė Astrauskiené $\dot{1}^{1}$ Jovita Vilkiené $\dot{1}^{1}$, \\ Karolis Urbanavičius ${ }^{1}$, Ovidijus Stropus ${ }^{1}$, Daiva Bartninkiene் ${ }^{2}$ \\ ${ }^{1}$ Kauno technologijos universiteto Edukologijos katedra, ${ }^{2}$ Leidykla , Šviesa“
}

Raktažodžiai: pradinių klasių mokiniai, fizinis pajègumas (FPJ).

\begin{abstract}
Santrauka
Tyrimas vyko 2016 m. rugsèjo-gruodžio mèn. aštuoniuose Lietuvos pradinio ugdymo ir pradinio ugdymo klases turinčiose bendrojo lavinimo mokykloje. Tyrime dalyvavo $1-2$ klasių mokiniai $(n=780)$, iš jų 390 mergaičių ir 390 berniukų. Mokiniams per kūno kultūros pamokas buvo atlikti keturi fizinio pajègumo testai: šuolis i toli iš vietos dviem kojom $(\mathrm{cm})$; medicininio (kimštinio) $1 \mathrm{~kg}$ kamuolio stūmimas nuo krūtinès (m); 3x10 m bègimas (s); pasilenkimas žemyn $(\mathrm{cm})$. Skirtumai tarp skirtingų lyčių, amžiaus ir fizinio pajegumo vertinimo nustatyti naudojant vienfaktorinę dispersinę analizę (ANOVA). Ryšiai tarp kintamujų apskaičiuoti remiantis Pirson'o (Pearson) $r$ koreliacijos koeficientu.

Rezultatai. $7 \mathrm{~m}$. vaikų šuolio ị toli iš vietos testo rezultatai: 105,2 cm (mergaičių) 118,3 cm (berniukų) $(\mathrm{p}<0,05)$. Medicininio (kimštinio) $1 \mathrm{~kg}$ kamuolio stūmimo nuo krūtinès testas: mergaitès $-2,73 \mathrm{~m}$, berniukai $-3,35 \mathrm{~m} .(\mathrm{p}<0,05) .8$ metų amžiaus berniukų šuolio ị tolị testo rezultatas $-131,2 \mathrm{~cm}$, o mergaičiu - 118,4 cm $(\mathrm{p}<0,05)$. Pasilenkimo žemyn testo rezultatai: mergaitès $-1,97 \mathrm{~cm}$, o berniukai $-2,3 \mathrm{~cm}$ $(\mathrm{p}<0,05)$.

Išvada. Jaunesniojo mokyklinio amžiaus vaikų fizinis pajègumas su amžiumi gereja. Tačiau vikrumo, lankstumo bei kojų raumenų staigioji jëga yra žemo lygio.
\end{abstract}

\section{Ivadas}

Šiuolaikinis mokslas fizini pajègumą pripažista kaip vieną iš svarbiausių sveikatos rodiklių, ypač prognozuojant sergamumo lètinėmis neinfekcinèmis ligomis ir jų sukelto mirtingumo rizikos laipsnị [1]. Šiandieną nustatyti atvirkštiniai ir tiesiniai ryšiai tarp suaugusiujų kasdienio fizinio aktyvumo, fizinio pajëgumo ir visų priežasčių mirtingumo, bendro sergamumo širdies ir kraujagyslių sistemos ligomis, išeminès širdies ligos paplitimo bei jų sukelto mirtingumo dažnio, 2 tipo diabeto paplitimo [2]. Fizinis pajėgumas yra individo sveikatos kokybinis rodiklis. Tai atspindi bendraji organizmo prisitaikymą prie fizinio krūvio, funkcijų optimizavimą sprendžiant užduotis, susijusias su motorine veikla, efektyviausiai naudojant organizmo resursus atsako metu $\mathfrak{i}$ išorinius dirgiklius. Gerèjant fiziniam pejègumui, ịvairūs motoriniai dirgikliai sukelia nespecifinę adaptaciją žmogaus organizme, funkciniame, motoriniame ir psichiniame lygyje. Mokslo literatūroje dažniausiai pateikiami sveikatos ir fizinio aktyvumo ryšio tyrimų duomenys, o fizinis pajègumas vertinamas kaip reikšmingas sveikatos būklès rodiklis [3]. Kontroliuojant vaikų fizini aktyvumą galima kontroliuoti jų fizinio pajègumo kaitą. Pastarujų metų moksliniai tyrimai atskiruose Europos regionuose pateikia skirtingus vaikų fizinio aktyvumo rodiklių duomenis, tačiau daugelyje šalių daugiau nei 50 proc. jaunesniojo mokyklinio amžiaus vaikų yra nepakankamai fiziškai aktyvūs $[4,5]$. Nustatyta, kad mažiausiai fiziškai aktyvių vaikų yra Pietų Europos šalyse, daugiausia - Šiaurès ir Rytų Europos regionuose [6]. Lietuvoje mokslinių darbų, kuriuose būtų analizuojamas jaunesniojo mokyklinio amžiaus vaikų, ypač pirmokų, fizinis aktyvumas bei fizinis pajègumas nèra daug. Tyrimų duomenimis, fizinis pasyvumas vyrauja tarp daugumos Lietuvos mokiniu [7]. Daugiau nei pusė pradinių klasių mokinių žiūri po vieną valandą per parą televizorių, o savaitgaliais ir šventinemis dienomis dar ir ilgiau. Mokiniai nèra pratę būti ir žaisti lauke. Kasdien lauke bent po dvi valandas būna tik pusė vaikų [8]. Pradejjus lankyti mokyklą keičiasi vaikų dienos režimas, veiklos pobūdis. Vietoj judrių žaidimų vaikai didelę dienos dali praleidžia mokyklos suole, ženkliai mažèja jų fizinis aktyvumas. R. Rutkauskaite ir J. Bukauskè [9] nustatè, kad aktyvių pradinių klasių mokinių yra tik 33,6 \%, tačiau fiziškai pasyvių - 66,4\%. Tačiau R. Stukas ir kt. [10] ištyrè, kad dauguma pradinių klasių mokinių yra fiziškai aktyvūs, ne- 
pakankamai fiziškai aktyvūs mokiniai sudaro penktadalị populiacijos. Nustatyta, kad fiziškai aktyvūs vaikai yra fiziškai pajègesni nei mažiau aktyvūs. Nors vaikų ir paauglių fizinis pajègumas daugiausia priklauso nuo genetinio paveldimumo [11], tačiau juos veikia ir kasdienis fizinis aktyvumas, sveikatos būklè [12, 13]. V. Žaltauskès ir A.Petrauskienès [14] atlikta studija rodo, kad dauguma Lietuvos pirmokų 2008, 2010 ir 2013 m. buvo pakankamai fiziškai aktyvūs. Daugiau nei pusè šalies pirmokų pèsčiomis nuvykdavo ir grįždavo iš mokyklos. Daugiau nei pusė jų darbo dienomis ir savaitgaliais 2-3 val. žaisdavo fiziškai aktyvius žaidimus lauke ir trečdalis lankè sporto ar šokių būrelius. Tačiau stebima visų minètų rodiklių mažèjimo tendencija [14].

Mokslo literatūroje stokojama tyrimų apie pradinių klasių mokinių fizinị pajègumą.

Šis tyrimo tikslas - ištirti jaunesniojo mokyklinio amžiaus vaikų fizinį pajègumą Lietuvoje.

\section{Tyrimo objektas ir metodika}

Tyrimui atlikti buvo sudaryta reprezentatyvi imtis, kuri leidžia pamatyti ir ịvertinti visos Lietuvos minèto amžiaus vaikų fizini pajègumą išskirtuose testuose bei tyrimo rezultatus reprezentuoti visai minètų amžiaus grupių vaikų populiacijai.

Remiantis SVIS duomenų bazès duomenimis [15], 2016/ 2017 mokslo metais pirmose klasèse mokèsi 30912 mokinių (iš jų 15050 mergaičių), antrose klasėse - 29112 (iš jų 14182 mergaitès). Imtis buvo skaičiuojama 95 proc. patikimumo, 5 proc. sklaidos intervale. Iš viso buvo numatyta testuoti 379 pirmų klasių mokinius ir 379 antrų klasių mokinius. Pagal mokyklų išdėstymą teritoriniu principu buvo parinktos mokyklos, kurios atspindètų visą Lietuvos populiaciją: dideli miestai, savivaldybių centrai, kaimai.

Tyrimas vyko 2016 m. rugsèjo-gruodžio mèn. aštuoniose Lietuvos pradinio ugdymo ir pradinio ugdymo klases turinčiose bendrojo lavinimo mokyklose. Tyrimo laikas ir vieta, gavus tèvų sutikimą, buvo iš anksto suderinti su mokyklos administracija. Tyrime dalyvavo 1-2 klasiu mokiniai ( $\mathrm{n}=$ 780), iš jų 390 mergaičių ir 390 berniukų (1 lent).

Fizinio pajègumo testavimas. Mokiniai per kūno kultūros pamokas atliko keturis fizinio pajègumo (FPJ) testus, testai aprašyti EUROFITE [16], P. Ivanovo, L. Paškevičienès, [17], Fjørtoft ir kt. [18] moksliniuose straipsniuose. Lankstumo testas specialiai buvo atliekamas palengvintomis priemonėmis ir kryptingai atliekamas siekiant ịvertinti mokiniu lankstumą. Šuolio ị tolį iš vietos testu nustatyta mokinių kojų raumenų staigioji jèga; bėgimo šaudykle $3 \times 10 \mathrm{~m}$ testu vikrumas; medicininio (kimštinio) 1 kg kamuolio stūmimu nuo krūtinès testu - rankų staigioji jèga.

Šuolis ị tolị iš vietos dviem kojom (cm). Fizinio pa- jègumo požymis - staigioji kojų raumenų jẻga $[17,18]$. Atsistojama prie linijos, pédos pastatomos lygiagrečiai, 8-10 $\mathrm{cm}$ atstumu viena nuo kitos, truputi pritupiama, pasilenkiama ì priekį, ritmingai keletą kartų pasiūbuojama - rankomis mojant pirmyn išsitiesiama, o atgal - pritupiama. Iš padèties pritūpus (rankos už nugaros) atsispiriama ir, išmojant rankas aukštyn, šokama i tolį. Skriejant oru liemuo laikomas tiesiai, kojos - šiek tiek pritrauktos prie savęs. Prieš nusileidžiant liemuo lenkiamas ị prieki, kojos energingai mojamos ị priekị, liemuo lenkiamas prie kojų. Testui atlikti skirti 3 bandymai, užrašomas geriausias bandymas, kai nušokama toliausiai.

Medicininio (kimštinio) 1 kg kamuolio stūmimas nuo krūtinès (m). Fizinio pajègumo požymis - rankų raumenų jèga [18]. Medicininio (kimštinio) kamuolio stūmimas (1 kg) dviem rankomis, metant kuo toliau. Pradinè stūmimo padètis - kojos lygiagrečiai viena kitai ir statomos pečių plotyje, kamuolys laikomas ir stumiamas rankomis nuo krūtinès. Rezultatas - nustumto kimštinio kamuolio atstumas (matuojamas metrais). Atliekami du bandymai, fiksuojamas geriausias rezultatas.

3x10 m bẻgimas (s). Fizinio pajègumo požymis - vikrumas, greitis [17]. Salèje $10 \mathrm{~m}$ atstumu pastatomi du estafečių kūgiai. Bègama nuo vieno iki kito kūgio, šis apibėgamas (aplenkiamas), tada bėgama atgal iki pirmo kūgio, šis irgi apibėgamas ir vẻl bėgama iki antro kūgio. Ṣ̌ atstumą reikia ịveikti kuo greičiau ir laikas stabdomas, kai mokinys atbėga iki antro kūgio ir kerta juo žymimą finišą, t. y. nubėgs $3 \times 10 \mathrm{~m}$. Kūgius reikia stengtis aplenkti kuo mažesniu atstumu, $i$ juos netgi galima remtis ranka. Testui atlikti skiriamas 1 bandymas.

Pasilenkimas žemyn (cm). Fizinio pajègumo požymis - lankstumas. Atsistojama ant gimnastikos suoliuko, stovima suglaustomis kojomis. Lenktis pirmyn (žemyn), kojos suglaustos. Atliekant pasilenkimą pirmyn (žemyn) svarbu, kad kojos būtų ištiestos per kelius.

Matematinė statistika. Duomenims palyginti buvo nustatomas aritmetinis vidurkis (x) ir vidutinis standartinis nuokrypis (SN). Skirtumai tarp skirtingų lyčių, amžiaus ir fizinio pajëgumo vertinimo nustatyti naudojant vienfaktorinę dispersinę analizę (ANOVA). Ryšiai tarp kintamujų apskaičiuoti remiantis Pirson'o (Pearson) r koreliacijos koeficientu. Naudoti tokie statistinių išvadų patikimumo lygiai: $p>0,05$ - nepatikima; $\mathrm{p}<0,05$ - patikima.Visi skaičiavimai atlikti MS Excell ir SPSS programomis.

\section{Tyrimo rezultatai}

7 metų mokinių fizinis pajègumas. Analizuojant 7 metų pradinių klasių mokinių (berniukų, mergaičių) fizinio pajègumo (FPJ) testų rezultatus paaiškejjo, kad šuolio ị tolị iš vietos testo rezultatai svyravo nuo 105,2 cm (mergaičių) iki 
$118,3 \mathrm{~cm}$ (berniukų), nustatyti statistiškai reikšmingi skirtumai $(\mathrm{p}<0,05)$ (2 lent.). Medicininio (kimštinio) $1 \mathrm{~kg}$ kamuolio stūmimo nuo krūtinès testą mergaitès atliko prasčiau $(2,73 \mathrm{~m})$ nei berniukai $(3,35 \mathrm{~m})(\mathrm{p}<0,05)$.

Geriausias mergaičių bėgimo šaudykle $3 \times$ $10 \mathrm{~m}$ rezultatas buvo $9,55 \mathrm{~s}$, berniuku $-9,2 \mathrm{~s}$, prasčiausias šio testo berniukų atlikimo laikas $-13,68 \mathrm{~s}$, mergaičiu - 13,54 s ( $<<0,05)$. Lyginant berniukų ir mergaičių lankstumo rezultatus, nenustatyti statistiškai reikšmingi skirtumai $(\mathrm{p}>$ $0,05)$ : mergaitès pasilenkè žemyn vidutiniškai apie $0,05 \mathrm{~cm}$, berniukai $--1,6 \mathrm{~cm}$ (2 lent.).

Tarp šuolio ị tolị iš vietos ir bégimo šaudykle $3 \times 10 \mathrm{~m}$ testo rezultatu $(\mathrm{r}=-0,939, \mathrm{p}<0,01)$; tarp šuolio ị toli iš vietos ir medicininio (kimštinio) $1 \mathrm{~kg}$ kamuolio stūmimo nuo krūtinès ( $\mathrm{r}$ $=-0,945, \mathrm{p}<0,01)$; tarp šuolio ị tolị iš vietos ir pasilenkimo žemyn $(r=0,945, p<0,01)$ nustatyti statistiškai reikšmingi koreliaciniai ryšiai. Tarp bėgimo šaudykle $3 \times 10 \mathrm{~m}$ testo rezultatų ir medicininio (kimštinio) $1 \mathrm{~kg}$ kamuolio stūmimo nuo krūtinès $(\mathrm{r}=-0,960, \mathrm{p}<0,01)$; tarp bègimo šaudykle $3 \times 10 \mathrm{~m}$ testo ir pasilenkimo žemyn $(\mathrm{r}$ $=0,949, \mathrm{p}<0,01)$ nustatytas teigiamas stiprus koreliacinis ryšys. Tarp medicininio (kimštinio) $1 \mathrm{~kg}$ kamuolio stūmimo nuo krūtinès ir pasilenkimo žemyn $(\mathrm{r}=0,942, \mathrm{p}<0,01)$ nustatytas taip pat teigiamas stiprus koreliacinis ryšys (3 lent.).

8 metụ mokinių fizinis pajègumas. Analizuojant 8 metų amžiaus berniukų ir mergaičių FPJ rodiklius nustatyta, kad geriausias berniukų šuolio ị tolị testo rezultatas buvo $131,2 \mathrm{~cm}$, o mergaitès nušoko ženkliai arčiau $(118,4 \mathrm{~cm})(\mathrm{p}<$ $0,05)$. Geriausias bėgimo šaudykle $3 \times 10 \mathrm{~m}$ laikas buvo $8,15 \mathrm{~s}$ (berniukai),o blogiausias rezultatas $-15,58 \mathrm{~s}$ (berniukai) $(\mathrm{p}<0,05)$. Mergaičių geriausias bègimo rezultatas $-8,08 \mathrm{~s}$, blogiausias $-13,41 \mathrm{~s}(\mathrm{p}<0,05)$. Lyginant medicininio (kimštinio) $1 \mathrm{~kg}$ kamuolio stūmimo nuo krūtinès testo rezultatus, tarp berniukų ir mergaičiu nustatytas statistiškai reikšmingas skirtumas $(\mathrm{p}<0,05)$ : toliausiai kamuoli nustūmè berniukai - 3,95 m, o mergaitès $-3,23 \mathrm{~m}$. Tarp mergaičių ir berniukų pasilenkimo žemyn testo rezultatų taip pat nustatytas statistiškai reikšmingas skirtumas $(\mathrm{p}<$ $0,05)$ : mergaitès maksimaliai pasilenkè žemyn $1,97 \mathrm{~cm}$, o berniukai - 2,3 cm (2 lent.).

Tarp šuolio ị tolį iš vietos ir bègimo šaudykle $3 \times 10 \mathrm{~m}$ testo rezultatu $(\mathrm{r}=0,212, \mathrm{p}<0,01)$; tarp šuolio ị tolị iš vietos ir medicininio (kimštinio) $1 \mathrm{~kg}$ kamuolio stūmimo nuo krūtinès $(\mathrm{r}=-0,916, \mathrm{p}<0,01)$; tarp šuolio ị tolị iš vietos ir pasilenkimo žemyn $(r=0,801, p<0,01)$ nustatyti statistiškai reikšmingi koreliaciniai ryšiai. Tarp bėgimo šaudykle $3 \times 10 \mathrm{~m}$ testo rezultatų ir medicininio (kimštinio) $1 \mathrm{~kg}$ kamuolio stūmimo nuo krūtinès $(\mathrm{r}=-0,054$, $\mathrm{p}<0,01)$; tarp bėgimo šaudykle $3 \times 10 \mathrm{~m}$ testo ir pasilenkimo žemyn $(\mathrm{r}=0,188, \mathrm{p}<0,01)$ nustatytas teigiamas stiprus koreliacinis ryšys. Tarp medicininio (kimštinio) $1 \mathrm{~kg}$ kamuolio stūmimo nuo krūtinès ir pasilenkimo žemyn $(r=0,873, p<0,01)$ nustatytas taip pat teigiamas stiprus koreliacinis ryšys (3 lent.).

\section{Tyrimo rezultatų aptarimas}

Teigiama, kad mokinių fizinio pajègumo tyrimai yra aktualūs kūno kultūros teorijos ir metodikos specialistams [19]. Optimaliai panaudojama kiekvieno vaiko fizinio pajègumo struktūros analizè leidžia numatyti fizinio poveikio apimtį ir intensyvumą, akcentuojant dèmesi

1 lentelè. Tiriamųų charakteristika

\begin{tabular}{|l|l|l|l|l|}
\hline Variabilumas & \multicolumn{2}{|l|}{ Pirma klasė } & Antra klasė \\
\cline { 2 - 5 } & $\begin{array}{l}\text { (mergaitės } \\
\mathbf{n}=\mathbf{1 9 5})\end{array}$ & $\begin{array}{l}\text { (berniukai } \\
\mathbf{n}=\mathbf{1 9 5})\end{array}$ & $\begin{array}{l}\text { (mergaitės } \\
\mathbf{n = 1 9 5}\end{array}$ & $\begin{array}{l}\text { (berniukai } \\
\mathbf{n}=\mathbf{1 9 5})\end{array}$ \\
\hline Amžius (metai) & $6(0,5)$ & $6(0,47)$ & $7(0,32)$ & $7(0,5)$ \\
\hline Svoris $(\mathrm{kg})$ & $21,85(5,38)$ & $21,2(4,61)$ & $122,12(8,91)$ & $124,65(9,38)$ \\
\hline Ūgis $(\mathrm{cm})$ & $117,42(5,36)$ & $117,98(9,16)$ & $26,12(6,02)$ & $25,65(7,24)$ \\
\hline
\end{tabular}

2 lentelè. 7-8 metų amžiaus berniukų ir mergaičių fizinio pajẻgumo rodiklių palyginimas

\begin{tabular}{|c|c|c|c|c|}
\hline Testo pavadinimas & Mergaitės & Berniukai & $\begin{array}{l}\text { F kriterijaus } \\
\text { reikšmė; } \\
\text { p lygmuo } \\
\end{array}$ & $\begin{array}{c}\text { Observed } \\
\text { Power (testo } \\
\text { galingumas) } \\
\end{array}$ \\
\hline \multicolumn{5}{|c|}{7 metų amžiaus tiriamieji (1 klasè) } \\
\hline $\begin{array}{l}\text { Šuolis ị tolị iš vietos } \\
\text { dviem kojom }(\mathrm{cm}) .\end{array}$ & $105,2(12,1)$ & $118,3(9,8)$ & $\begin{array}{c}28: 017 \\
0: 000\end{array}$ & $1: 000$ \\
\hline $\begin{array}{l}\text { Medicininio (kimš- } \\
\text { tinio) } 1 \text { kg kamuolio } \\
\text { stūmimas nuo krūti- } \\
\text { nès (m). }\end{array}$ & $2.73(0,27)$ & $3.35(0,65)$ & $\begin{array}{c}73: 460 \\
0: 000\end{array}$ & $1: 000$ \\
\hline $3 \times 10 \mathrm{~m}$ bègimas. & $\begin{array}{c}11,61 \\
(0,914)\end{array}$ & $\begin{array}{c}10,99 \\
(1,06) \\
\end{array}$ & $\begin{array}{c}21: 082 \\
0: 000 \\
\end{array}$ & $0: 996$ \\
\hline $\begin{array}{l}\text { Pasilenkimas žemyn } \\
(\mathrm{cm}) .\end{array}$ & $0,05(7,09)$ & $-1,6(6,25)$ & $\begin{array}{l}3: 475 \\
0: 064\end{array}$ & $0: 459$ \\
\hline \multicolumn{5}{|c|}{8 metų amžiaus tiriamieji (2 klasè) } \\
\hline $\begin{array}{l}\text { Šuolis ị tolị iš vietos } \\
\text { dviem kojom }(\mathrm{cm}) .\end{array}$ & $118,4(17,4)$ & $\begin{array}{l}131,2 \\
(20,1) \\
\end{array}$ & $\begin{array}{c}28: 138 \\
0: 000 \\
\end{array}$ & $1: 000$ \\
\hline $\begin{array}{l}\text { Medicininio (kimš- } \\
\text { tinio) } 1 \text { kg kamuolio } \\
\text { stūmimas nuo krūti- } \\
\text { nès }(\mathrm{m}) \text {. }\end{array}$ & $3.23(0,56)$ & $3.95(0,74)$ & $\begin{array}{c}69: 520 \\
0: 000\end{array}$ & $1: 000$ \\
\hline $3 \times 10 \mathrm{~m}$ bègimas. & $10,99(0,98)$ & $\begin{array}{l}10,66 \\
(1,22) \\
\end{array}$ & $\begin{array}{c}5: 213^{*} \\
0: 023\end{array}$ & $0: 623$ \\
\hline $\begin{array}{l}\text { Pasilenkimas žemyn } \\
\text { (cm). }\end{array}$ & $1,97(6,1)$ & $-2,3(6,5)$ & $\begin{array}{c}25: 725 \\
0: 000\end{array}$ & 0:999 \\
\hline
\end{tabular}


i atitinkamus požymius. Žinant konkretaus vaiko gebejjimus, galima taikyti fizinius pratimus, kurie stiprintų sveikatą, bei individualiai parinkti pratimus, kurie darytų teigiamą poveiki jų fiziniam vystymuisi [20].

Straipsnyje pateikiamas jaunesniojo mokyklinio amžiaus vaikų fizinis pajègumas Lietuvoje. Pateikiami FPJ testai, kurie paprasti naudoti ir atspindi pradinių klasių mokinių fizinį aktyvumą, rankų raumenų jègą, motorinius igūdžius, koordinaciją, lankstumą, vikrumą.

Fizinio pajègumo testų rezultatai buvo vertinami pagal S. Norkaus [19] sukurtas fizinio išsivystymo ir fizinio pajègumo referencines lenteles. Lentelès leido suskirstyti mokinius pagal fizinio pajègumo lygius. Pradinių klasių mokinių kojų raumenų staigioji jëga yra žemo lygio [19]. Statistiškai reikšmingi skirtumai yra nustatyti tarp 7 ir 8 metų mokinių $(p<0,05)$. Mūsų gauti rezultatai, palyginti su R. Rutkauskaitès ir J. Bukauskès [9] atliktu tyrimu, parodè, kad $8 \mathrm{~m}$. mergaičiu $(118,4 \pm 17,4)$ ir berniuku $(131,2 \pm 20,1)$ šuolio ị tolị iš vietos rezultatai yra geresni nei autorių. Mokslininkès nustatè, kad mergaičių šuolio $i$ tolį iš vietos rezultatai yra $104,5 \pm 21,1$, berniuku $-108,9 \pm 26,3$. Tačiau graikų mokslininkų atlikti tyrimai parodè, kad Graikijoje gyvenančių mergaičių šuolio ị tolị iš vietos rezultatas yra geresnis $(141 \pm 1,2 \mathrm{~cm})$ nei Lietuvoje besimokančių mergaičių, berniukų rezultatai yra panašūs $(132 \pm 0,2 \mathrm{~cm})$ [21].

Lietuvoje yra mažai duomenų apie daikto (1000 g) metimo ị tolị iš vietos rezultatus. F. Biskanaki ir kt. [22] atliktame tyrime nustatyta, kad 8 metu mergaitės kamuoliuką nustumia vidutiniškai 3,61 $\pm 0,79 \mathrm{~m}$, berniukai $-4,17 \pm$ $0,85 \mathrm{~m}$. Mūsų gauti testo rezultatai yra šiek tiek mažesni. Mergaitès medicininị $1 \mathrm{~kg}$ kamuolio nustūmė nuo krūtinès vidutiniškai 3,23 $\pm 0,56 \mathrm{~m}$, berniukai $3,95 \pm 0,74 \mathrm{~m}$.

Nustatyta, kad su amžiumi buvo fiksuojamas vis geresnis bėgimo šaudykle $3 \times 10 \mathrm{~m}$ mergaičių testo rezultatas, berniukų lieka panašus. Remiantis P. Ivanovo ir L. Paškevičienès [17] fizinio išsivystymo ir fizinio pajejgumo referencinėmis lentelemis, mergaičių vikrumas yra labai žemo, o berniukų - žemo lygio.

3 lentelè. Mokinių fizinio pajėgumo tarpusavio ryšiai $* *-p<0.01$

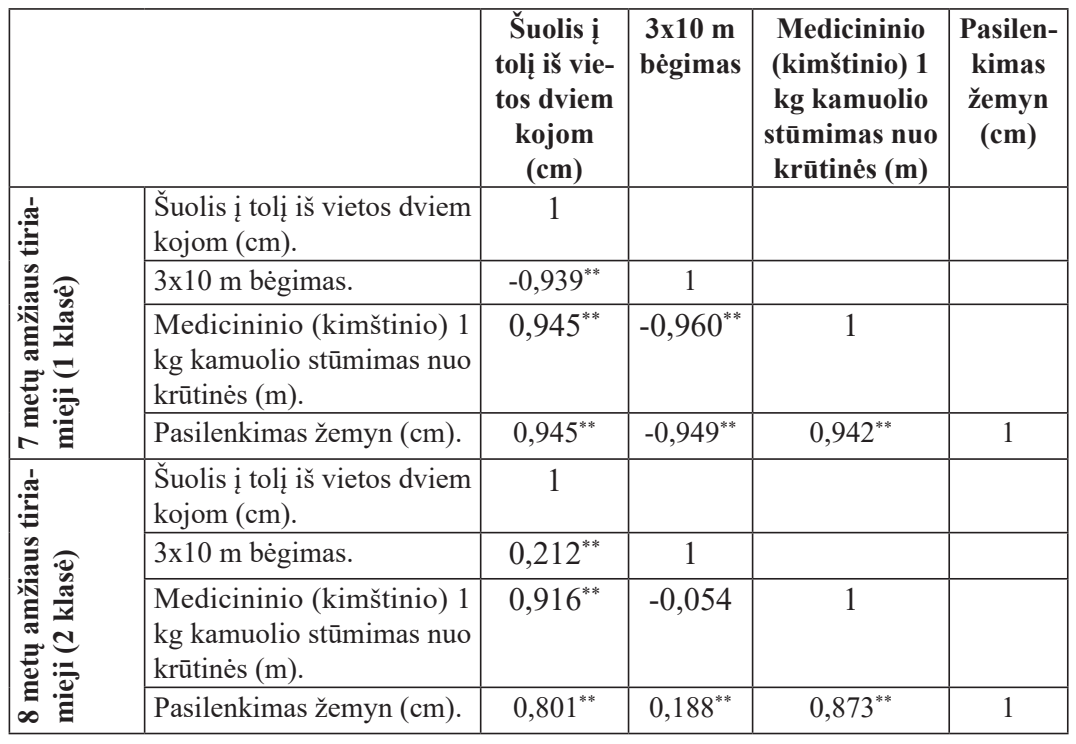

Nustatyta, kad lankstumo vystymasis yra tiesiogiai susijęs su amžiumi. Jaunesniame mokykliniame amžiuje lankstumo vystymasis tarp berniukų ir mergaičių skiriasi [23). Atlikus modifikuotą lankstumo testą „Pasilenkimas žemyn“, nustatyta, kad mergaičių apatinès nugaros dalies lankstumo rodikliai yra kur kas geresni nei berniukų ( $<<0,001)$. Lankstumas mergaitems vystosi nuo 5 iki 11 metų, o berniukams lankstumo vystymasis lètesnis ties 5 ir 12 metų amžiumi. Tačiau nepaisant šių faktų, jaunesnis mokyklinis amžius yra labai svarbus lankstumui ugdyti [13].

Išanalizavus pradinių klasių mokinių fizinio pajègumo rezultatus paaiškejjo, kad beveik visų testų rezultatai gerejja mokiniui augant. Taigi darome prielaidą, kad fizinio aktyvumo trūkumas yra viena mažo fizinio pajègumo priežasčių.

\section{Išvada}

Jaunesnio mokyklinio amžiaus vaikų fizinis pajègumas su amžiumi gerèja. Tačiau vikrumo, lankstumo bei kojų raumenų staigioji jèga yra žemo lygio.

\section{Literatūra}

1. Lohman TG, Ring K. Pfeiffer K, Camhi S, Arredondo E, Pratt C, Pate R, Webber LS. Relationships among fitness, body composition, and physical activity. Med Sci Sports Exerc 2008; 40(5): 1163-1170.

https://doi.org/10.1249/

MSS.0b013e318165c86b

2. Jackson AS, Stanforth P R, Gagnon J, Rankinen T, Leon AS, Rao DC, Skinner JS, Bouchard C, Wilmore JH. The effect of sex, age and race on estimating percentage body fat from body mass index: The Heritage Family Study. Int J Obes Int J Obes 2002; 26(6): 789-796.

3. Bouchard C, Shephard RJ. Physical activity, fitness and health: the model and key concepts. In C. Bouchard, R. J. Shephard and T. Stephens (Eds.), Physical activity, fitness and health. Champaigne: Human Kinetics, 1994.

https://doi.org/10.1249/00005768199401000-00024

4. Ahrens W, Bammann K, Siani A, Buchecker 
K, De Henauw S, Iacoviello L. IDEFICS consortium. The IDEFICS cohort: design, characteristics and participation in the baseline survey. Int J Obes 2011; 35: S3-S15.

https://doi.org/10.1038/ijo.2011.30

5. Griffiths LJ, Cortina-Borja M, Sera F, Pouliou T, Geraci M, Rich C, Cole T, Law C, Joshi H, Ness A, Jebb S, Dezateux C. How active are our children? Findings from the Millennium. Cohort Study. BMJ Open 2013; 3(8): 1-10.

https://doi.org/10.1136/bmjopen-2013-002893

6. Konstabel K, Veidebaum T, Verbestel V, Moreno LA, Bammann $\mathrm{K}$, Tornaritis M. Objectively measured physical activity in European children: the IDEFICS study. Int J Obes 2014; 38(2): 135-143.

https://doi.org/10.1038/ijo.2014.144

7. ZaborskisA., RaskilasA.Lietuvos mokinių fizinioaktyvumo pokyčiai 1994-2010 metais. Visuomenès sveikata, 2011; 3(54): 78-86.

8. Adaškevičienė E. Vaikų fizinès sveikatos ir kūno kultūros ugdymas. Klaipėda: KU. 2004.

9. Rutkauskaitė R., Bukauskè J. Pradinių klasių mokinių fizinis aktyvumas, fizinis pajëgumas, mitybos įpročiai, pasiekimų ir pažangos vertinimas bei jų sąsajos su tèvų fiziniu aktyvumu. Sporto mokslas, 2016; 1(83): 34-42.

https://doi.org/10.15823/sm.2016.6

10. Stukas R., Kalibatienè D., Vingras A., Dobrovolskij V., Savickaja K. Vilniaus miesto pradinių klasių mokinių gyvensena ir sveikata. Medicinos teorija ir praktika, 2011; 17(4): 430-436.

11. Bouchard C. Heredity and health-related fitness. Research Digest. President's Council on Physical Fitness and Sports 1993; 10: 1-4.

12. Corbin CB, Pangrazi RP, Franks BD. Definitions: health, fitness and physical activity. Research Digest. President's Council on Physical Fitness and Sports 2000; 18: 1-8.

13. Malina RM, Bouchard C, Bar-Or O. Growth, maturation and physical activity. 2nd ed. Champaign IL: Human Kinetic Books 2004.

14. Žaltauskè V., Petrauskienė A. Lietuvos pirmų klasių mokinių fizinio aktyvumo pokyčiai penkerių metų laikotarpiu. tarptautinio COSI tyrimo duomenys (2008, 2010 ir 2013 m.). Visuomenès sveikata, 2016; 1(72): 69-75.

15. http://www.svis.smm.lt/

16. VolbekienėV., Kavaliauskas S. (Sud.) EUROFITAS. Fizinio pajègumo testai, metodika, Lietuvos moksleivių fizinio pajègumo rezultatai. Vilnius, LSIC, 2002.

17. Ivanovas P., Paškevičienė L. Kūno kultūros pamokų turinys (pirmoji klasė). Šiaurès Lietuva, 2003.

18. Fjørtoft I, Pedersen AV, Sigmundsson H, Vereijken B. Measuring physical fitness in children who are 5 to 12 years old with a test battery that is functional and easy to administer. Physical Therapy 2011; 91(7): 1087-1095.

https://doi.org/10.2522/ptj.20090350

19. Norkus S. Pradinukų fizinio pajègumo diagnostika. Metodinė priemonè. Šiaulių universiteto leidykla, 2002.

20. Visagurksienė K., Grigonienė J. Ikimokyklinio ir pradinio mokyklinio amžiaus vaikų fizinių ypatybių testavimas ir ugdymas. Metodiné priemoné pedagogams. LSU, 2016.

21. Veligekas P, Tsoukos A, Bogdanis GC. Determinants of standing long jump performance in 9-12 years old children. Serb J Sports Sci 2012; 6(4): 147-155.

22. Biskanaki F, Panagiotou AK, Papadopoulou SK, Spiridou NG, Gallos GK, Jaswinder Gill, Zacharis EM, Tassoulas E, Fachantidou A. ÔThe effect of sex and obesity on specific motor skills of Greek children aged 8 years old. Pakistan J. Med. Res 2004; 43 (3): 22-28.

23. Česnaitienė V. J., Emeljanovas A., Miežienė B. Ikimokyklinio ir pradinio mokyklinio amžiaus vaikų fizinio pajègumo vertinimo metodika. Metodinè medžiaga, LSU, 2016.

\section{PRIMARY SCHOOL CHILDREN'S PHYSICAL CAPA-} BILITY ANALYSIS LITHUANIA: STUDY YEAR 2016

I. Klizienė, G. Cibulskas, A. Astrauskienė, J. Vilkienė, K. Urbanavičius, O. Stropus, D. Bartninkienė

Key words: primary school children's, physical capability.

Examination's materials and methods. The study took place during September-December in 2016, in the eight Lithuanian primary education classes. The study included students from 1-2 grade $(\mathrm{n}=780)$, including 390 girls and 390 boys. During physical education classes, students took four physical capacity's (FPJ) tests: the long jump from the place with two feet $(\mathrm{cm})$; the pushing of 1 $\mathrm{kg}$ medical (stuffed) ball from the breast, (m); 3x10 m track race (s); the bending down $(\mathrm{cm})$. The differences between a different gender, age and physical fitness were evaluated using the univariate dispersible analysis (ANOVA). The relations between variables were calculated based on Pearson's correlation coefficient $r$.

Results. 7-year-old children's long jump from the place tests results: $105.2 \mathrm{~cm}$ (girls) $118.3 \mathrm{~cm}$ (boys) $(\mathrm{p}<0.05)$. The pushing of $1 \mathrm{~kg}$ medical (stuffed) ball from the breast: girls $-2,73 \mathrm{~m}$, the boys - $3.35 \mathrm{~m}$. ( $\mathrm{P}<0.05)$. 8-year -old boys' long jump test results $-131.2 \mathrm{~cm}$ and girls $-118.4 \mathrm{~cm}(\mathrm{p}<0.05)$. The results of the bending down tests: girls $-1.97 \mathrm{~cm}$., and the boys $-2.3 \mathrm{~cm}$. $(\mathrm{P}<0.05)$ Conclusion. The physical capacity of younger school-aged children with age is improving. However, agility, flexibility, and leg muscle's explosive power is low.

Correspondence to: irina.kliziene@ktu.lt

Gauta 2017-06-13 